\title{
Post-Acute Care Reform: Implications and Opportunities for Hospitalists
}

\author{
Robert E. Burke, MD, MS $1,2,3 *$ Ethan Cumbler, $\mathrm{MD}^{3}$, Eric A. Coleman, MD, MPH${ }^{4}$, Cari Levy, MD, $\mathrm{PhD}^{1,4}$
}

${ }^{1}$ Research Section and ${ }^{2}$ Hospital Medicine Section, Denver VA Medical Center, Denver, Colorado; ${ }^{3}$ Division of General Internal Medicine and ${ }^{4}$ Division of Health Care Policy and Research, University of Colorado School of Medicine, Aurora, Colorado.

\begin{abstract}
Nearly all practicing hospitalists have firsthand experience discharging patients to post-acute care (PAC), which is provided by inpatient rehabilitation facilities, skilled nursing facilities, or home healthcare providers. Many may not know that PAC is poised to undergo transformative change, spurred by recent legislation resulting in a range of reforms. These reforms have the potential to fundamentally reshape the relationship between hospitals and PAC providers. They have important implications for hospitalists and will open up
\end{abstract}

opportunities for hospitalists to improve healthcare value. In this article, the authors explore the reasons for PAC reform and the scope of the reforms. Then they describe the implications for hospitalists and hospitalists' opportunities to Choose Wisely and improve healthcare value for the rapidly growing number of vulnerable older adults transitioning to PAC after hospital discharge. Journal of Hospital Medicine 2017;12:46-51. (C) 2017 Society of Hospital Medicine
The landscape of post-acute care (PAC), which is predominantly provided by inpatient rehabilitation facilities (IRFs), skilled nursing facilities (SNFs), and home healthcare (HHC) providers, is rapidly changing. As hospitalizations shorten, PAC utilization is rising, resulting in rapidly increasing costs. ${ }^{1-5}$ However, patient outcomes in PAC are characterized by high rates of readmission and low rates of return to the community. ${ }^{6,7}$ Emerging evidence suggests these outcomes could be substantially improved through use of better in-hospital and transitional care processes. ${ }^{8-10}$

Legislators took notice of the spiraling costs, potential quality concerns, and undesirable patient outcomes in PAC. Provisions in the Patient Protection and Affordable Care Act of 2010 (ACA), the Protecting Access to Medicare Act of 2014 (PAMA), and the Improving Medicare Post-Acute Care Transformation (IMPACT) Act of 2014 affect patient selection, payment, and quality measurement in PAC. As older adults are increasingly being cared for by hospitalists, ${ }^{11}$ hospitalists must be aware of the implications of these reforms.

\section{IMPLICATIONS FOR HOSPITALISTS Choosing Patients Wisely for PAC}

Because PAC-related decision making is not standardized, referral rates vary significantly. ${ }^{12}$ The variability in PAC use accounts for $79 \%$ of all regional variation in Medicare spending in the United States. ${ }^{13,14}$ Compared with other physicians, hospitalists are more likely to use $\mathrm{PAC}^{15}$ but typically receive little exposure to PAC during training. ${ }^{16}$

The IMPACT Act proposes 2 major changes to patient

\footnotetext{
*Address for correspondence and reprint requests: Robert E. Burke, MD, MS, Research and Hospital Medicine Sections, Denver VA Medical Center, 1055 Clermont St, Denver, CO 80220; Telephone: 303-399-8020 extension 2396; Fax: 303-393-5199; E-mail: robert.burke5@va.gov
}

Received: February 24, 2016; Revised: June 6, 2016; Accepted: June 28, 2016 2017 Society of Hospital Medicine DOI 10.1002/jhm.2673 selection: a uniform assessment tool for patients being discharged to PAC and "site-neutral" payments for PAC. Starting in 2018, the Continuity Assessment Record and Evaluation (CARE) tool must be completed before a hospital discharge in order to better match PAC resources to patient needs. The current 26-page CARE tool includes questions about demographics and home support, medical complexity, physical function, cognitive status, and "transition items," including discharge plans and advance directives. In pilot testing, significant amounts of missing data and average completion times of up to 60 minutes raised concerns about feasibility. ${ }^{17}$ CARE tool assessments accurately predicted what form of PAC patients actually received, but further testing is planned to validate whether the type of PAC selected was optimal for patient outcomes.. A plan for using CARE tool assessments to determine site-neutral payments is due to Congress by 2020. In the site-neutral payment system, the PAC provider will be reimbursed according to patient needs (identified by the CARE tool), regardless of PAC setting-a radical change from the current system, in which IRF, SNF, and HHC episodes show major differences in median costs (Table 1). ${ }^{18}$

Hospitalists may be concerned that use of the CARE tool will supplant clinical judgment about patients' PAC needs. The burden of completing the CARE tool could inadvertently reduce the amount of attention hospitalists give to other aspects of a safe discharge rather than lead to the improvement desired. ${ }^{19-21}$ Hospitalists will benefit from developing interdisciplinary, iterative workflows to complete the tool, improving accuracy and reducing the burden.

A potential unintended consequence of the site-neutral payment system may be increased difficulty discharging elderly patients who have limited rehabilitation potential but are lacking sufficient social support to return home. In the current system, these patients are commonly discharged to SNFs as a bridge to long-term nursing home care. Hospitalists will need to become increasingly familiar with novel al- 
TABLE 1. Overview of Most Common Post-Acute Care Options ${ }^{18}$

\begin{tabular}{|c|c|c|c|}
\hline & Inpatient Rehabilitation Facility & Skilled Nursing Facility & Home Healthcare Provider \\
\hline \multirow[t]{3}{*}{ Eligibility } & $\begin{array}{l}\text { Preceding hospital stay not required, but patient } \\
\text { without preceding stay responsible for more cost }\end{array}$ & $\begin{array}{l}\text { Preceding 3-night hospital stay required within } 30 \text { days } \\
\text { of SNF admission }\end{array}$ & Preceding hospital stay not required \\
\hline & $\begin{array}{l}\text { Patient requires and can tolerate } \geq 3 \text { hours of therapy } \\
5 \text { days per week }\end{array}$ & Patient must have daily skilled nursing or therapy need & $\begin{array}{l}\text { Patient must be "homebound" and require intermittent } \\
\text { nursing care or therapy }\end{array}$ \\
\hline & $\begin{array}{l}\text { More than } 60 \% \text { of IRF patients must fit into } 1 \text { of } 13 \\
\text { proscribed diagnostic categories (eg, stroke) }\end{array}$ & $\begin{array}{l}\text { Many facilities also provide long-term nursing home } \\
\text { care, which patients may transition into if they do not } \\
\text { rehabilitate successfully }\end{array}$ & $\begin{array}{l}\text { Home healthcare is disbursed in 60-day "episodes," } \\
\text { which can be renewed }\end{array}$ \\
\hline Payment (Medicare) ${ }^{\mathrm{a}}$ & $\begin{array}{l}\text { Patients pay no additional costs unless coming from } \\
\text { community ( } \$ 1260 \text { up front, } \$ 315 / \text { day for days 61-90) }\end{array}$ & $\begin{array}{l}\text { Patients have no copayment days } 1-20 \text { after hospital } \\
\text { discharge, then pay } \sim \$ 160 \text { per day during days } \\
21-100 \text {, then pay full cost. Benefit resets after } 60 \\
\text { consecutive days without using Medicare benefit }\end{array}$ & Patients pay no additional costs \\
\hline Mean Length of Stay ${ }^{a}$ & 12.9 days & 27.6 days & 1.9 episodes ( 120 days) \\
\hline
\end{tabular}

ternatives to nursing home-based care, such as home-based primary care, medical foster homes, and Medicare/Medicaid's Program of All-Inclusive Care of the Elderly (PACE). ${ }^{22-25}$

\section{Choosing PAC Providers Wisely}

Medicare's Nursing Home Compare tool (https://www.medicare. gov/nursinghomecompare/search.html) provides a "5-star" system for rating SNFs on several quality metrics; these metrics, however, are not correlated with readmission or mortality rates. ${ }^{26,27}$ Improving quality measurement in PAC and tying payment to quality and outcomes are major emphases of the IMPACT Act and PAMA, respectively. PAC providers must publicly report an expanded list of quality measures and outcomes by 2018. In 2017, SNFs will begin reporting rates of "potentially preventable" readmissions, and starting in 2019 they will face penalties for having high risk-adjusted rates.

These reforms coincide with an increased emphasis on hospitals and PAC providers sharing responsibility for costs and outcomes. One model of the Bundled Payments for Care Improvement (BPCI) initiative includes a single payment for an acute hospitalization and PAC up to 90 days after hospital discharge for select conditions. The Medicare Spending Per Beneficiary (MSPB) measure compares hospitals on their spending for Medicare beneficiaries from 3 days before hospital admission to 30 days after hospital discharge, and penalizes outliers with high costs. ${ }^{28}$ PAC spending is the main driver of costs in both BPCI and MSPB. ${ }^{29}$ One way that hospitals have responded to the BPCI is by drastically reducing their referrals to SNFs and increasing their referrals to HHC providers; unfortunately, this response has resulted in increases in post-discharge emergency department visits. ${ }^{29,30}$ Taking a novel step in November 2015, the Centers for Medicare \& Medicaid Services (CMS) ruled that hospitals in more than 67 metropolitan service areas will be involuntarily enrolled in the BPCI initiative, using elective lower extremity joint replacement as the sample condition. ${ }^{31}$ This ruling signaled that these reforms are not meant solely for "high-performing" hospital and PAC systems able to volunteer for novel models of payment.

These changes have direct implications for hospitalists. Bundled payments incentivize hospitalists to reduce hospital length of stay and choose PAC alternatives with lower costs. SNFs may start accepting fewer "high-risk" patients in order to avoid readmission penalties. Hospitals will need to identify and partner with high-performing PAC providers in their community to maximize outcomes for their patients. On their websites, the Society of Post-Acute and LongTerm Care Medicine (AMDA) lists its state chapters, ${ }^{32}$ and the National Association for Home Care \& Hospice lists national HHC agencies. ${ }^{33}$ Reviewing early lessons learned in the evaluation of PAC providers as potential hospital partners in Pioneer accountable care organizations may be helpful, ${ }^{34}$ though the PAC cost savings in these organizations largely resulted from redirecting patients from SNFs to $\mathrm{HHC}$ providers. ${ }^{35,36}$ In many markets, the relationships between hospitals and PAC providers may become more formalized, leading to vertical integration. ${ }^{37}$ Hospitalists may increasingly be asked to work with, or even in, SNFs. ${ }^{38}$ For hospitalists who begin working in PAC, the AMDA is developing an educational curriculum to maximize efficacy in a new practice setting. ${ }^{39}$ In other markets, hospitals may turn to for-profit entities that provide "integrated post-acute care services," 40 taking over PAC decision making from inpatient teams and sharing any resulting profits from bundled payments. 
TABLE 2. High-Value Areas For Hospitalists to Address Before Discharge to Post-Acute Care

\begin{tabular}{|c|c|c|c|}
\hline $\begin{array}{l}\text { Ideal Transition } \\
\text { of Care Domain }^{\text {a }}\end{array}$ & Goals & Challenges & References \\
\hline Discharge Planning & $\begin{array}{l}\text { Assess cognitive, functional, and medical impairments } \\
\text { as well as social support to match PAC resources } \\
\text { to needs }\end{array}$ & $\begin{array}{l}\text { Accurate assessment challenging } \\
\text { No clear guidelines for matching needs to resources } \\
\text { Hospitalists may have less understanding of PAC capabilities/constraints }\end{array}$ & $16,73-77$ \\
\hline $\begin{array}{l}\text { Complete Communication of } \\
\text { Information }\end{array}$ & $\begin{array}{l}\text { Provide appropriate content in information transfer } \\
\text { to PAC }\end{array}$ & $\begin{array}{l}\text { Transfer information may not include elements desired by PAC clinicians } \\
\text { (eg medication indications, anticipated completion of time-limited medications) } \\
\text { Infrequent documentation of care goals, mental status, and physical function }\end{array}$ & $78-83$ \\
\hline $\begin{array}{l}\text { Availability, Timeliness, Clarity, } \\
\text { and Organization of Information }\end{array}$ & Transfer information in a timely and efficient manner & $\begin{array}{l}\text { Discharge summary arrives after patient } \\
\text { PAC and hospital seldom infrequently share electronic medical record } \\
\text { PAC clinicians may struggle to reach inpatient clinician to ask questions }\end{array}$ & 84,85 \\
\hline Medication Safety & $\begin{array}{l}\text { Effective in-hospital medication reconciliation, } \\
\text { accurate list of medications provided to PAC }\end{array}$ & $\begin{array}{l}\text { Medication list often inaccurate } \\
\text { Medication list may include medications known to cause adverse events in elderly }\end{array}$ & $8,9,86-90$ \\
\hline $\begin{array}{l}\text { Educate Patients, Promote } \\
\text { Self-Management }\end{array}$ & $\begin{array}{l}\text { Engage patients in their own medical care and } \\
\text { functional recovery }\end{array}$ & $\begin{array}{l}\text { Cognitive impairment common } \\
\text { Patients and caregivers may struggle to transition after long hospital/post- } \\
\text { acute care stay in which care was provided by others }\end{array}$ & $82,91-95$ \\
\hline $\begin{array}{l}\text { Enlist Help of Social and } \\
\text { Community Supports }\end{array}$ & $\begin{array}{l}\text { Identify high-performing PAC providers } \\
\text { for collaboration }\end{array}$ & $\begin{array}{l}\text { Medicare " } 5 \text {-star" ratings may not correlate with readmissions and consumer } \\
\text { perceptions and may exacerbate disparities } \\
\text { Unclear how to identify high-performing sites }\end{array}$ & $8,26,34,96,97$ \\
\hline Advance Care Planning & $\begin{array}{l}\text { Identify decision maker and care goals; palliative } \\
\text { referral when appropriate }\end{array}$ & $\begin{array}{l}\text { Hospitalization often chaotic, patient and caregiver participation difficult } \\
\text { Varying levels of comfort among providers who are having these conversations }\end{array}$ & $45,98-102$ \\
\hline $\begin{array}{l}\text { Coordinating Care Among Team } \\
\text { Members }\end{array}$ & $\begin{array}{l}\text { Coordinated evaluation before discharge and } \\
\text { with PAC provider }\end{array}$ & $\begin{array}{l}\text { Time-consuming bidirectional barriers to reaching responsible clinician } \\
\text { at other care site }\end{array}$ & 78,79 \\
\hline $\begin{array}{l}\text { Monitoring and Managing } \\
\text { Symptoms After Discharge }\end{array}$ & $\begin{array}{l}\text { Identify and treat acute medical issues before PAC } \\
\text { discharge to prevent readmission }\end{array}$ & $\begin{array}{l}\text { External influences to discharge patients to PAC "quicker and sicker" } \\
\text { Unclear expectations of level of monitoring PAC can and should provide } \\
\text { Limited medical training and increased turnover of frontline PAC staff }\end{array}$ & $2,4,8-10,103,104$ \\
\hline
\end{tabular}

aNot included is the tenth Ideal Transition of Care domain, Follow-Up With Outpatient Providers, which is more relevant to home discharges.

NOTE: Abbreviation: PAC, post-acute care.

\section{OPPORTUNITIES FOR HOSPITALISTS Improve Hospital and Transitional Care to Ensure Successful Early Outcomes in PAC}

Payment reform ensures hospitalists will increasingly have a stake in these matters, as joint responsibility for costs and outcomes increases for patients discharged to PAC. Hospitalists play a major role in these outcomes by deciding when and where to discharge patients and ensuring that optimal transition-of-care processes are used. ${ }^{8-10,41-45}$ Although no single intervention has been prospectively found to improve hospital-to-PAC transitional care outcomes, areas in need of improvement are known. Table 2 lists these within 9 of the Ideal Transition of Care Framework domains. ${ }^{43,46}$

\section{Advocate Patient-Centered PAC Placement That Maximizes Long-Term Outcomes}

Payment reforms could reinforce the cynical view that the optimal PAC setting is the least costly one that avoids hospital readmission. This view does not incorporate evidence that, in some cases, placement in a more costly PAC setting results in better long-term outcomes (eg, community discharge rates). ${ }^{47,48}$ It is also incongruent with a holistic view of the patient's needs, particularly for patients who may otherwise be suitable for home-based PAC but have limited social support. ${ }^{49}$ Finally, it does not acknowledge the reality that patients who are inadequately rehabilitated often tran- sition to long-term nursing home care, ${ }^{50}$ which could result in significant cost-shifting from Medicare to Medicaid, the predominant payer for long-term care. ${ }^{51}$ Given the extraordinary cost of long-term nursing home care, attending only to short-term costs and outcomes could increase national healthcare expenditures.

With most PAC-related decisions being made in the hospital, hospitalists find themselves at the center of a care team that must advocate the PAC that is best for the patient over the long term. This endeavor requires that hospitalists and others work for improvements in at least 3 aspects of in-hospital care. First, systems for accurately and reliably identifying patient factors that could substantially affect ability to rehabilitate (eg delirium) must be developed or enhanced. ${ }^{52-54}$ Second, more formal evaluation of the ability of patients and their caregivers to succeed at home is needed. ${ }^{55-60}$ Patients and caregivers may not understand their home needs without first "testing" the experience prior to discharge. ${ }^{61}$ Third, hospitalists must understand PAC in order to provide safe transitions. ${ }^{16}$ It is logistically challenging to expose practicing hospitalists to PAC, and it is unclear which exposures are most effective in improving decision making. ${ }^{62}$ An alternative approach that provides hospitalists with feedback about the short-and long-term outcomes of patients they have discharged to PAC may iteratively improve decision making. However, despite the high rate of 
discharges to PAC, there are anecdotal reports that few hospitalists receive feedback on patient outcomes.

As these reforms are tested and implemented, advocacy at regional and national levels is needed. The American Geriatrics Society (AGS), the AMDA, and the American Academy of Home Care Medicine all have well-developed advocacy platforms hospitalists can access. ${ }^{63-65}$

\section{Share Expertise to Improve Quality in a Constrained Environment}

There are opportunities for synergy between robust quality improvement (QI) efforts in PAC (often as part of Quality Assurance and Performance Improvement programs) and similarly robust hospital QI efforts led by hospitalists. ${ }^{66-70}$ These efforts have largely occurred in parallel, but now some important bridging QI interventions (eg, collaborative root cause analyses for patients readmitted after PAC) are starting at some sites, and these may drive improvement across the care spectrum. ${ }^{45}$ The Society of Hospital Medicine, the AGS, and the AMDA have written White Papers on care transitions that may serve as starting points for discussion. ${ }^{41,71,72}$

\section{CONCLUSION}

PAC is rapidly changing in response to reform legislation that is intended to address poor outcomes and high costs. Hospitalists will increasingly feel the effects of these reforms in their day-to-day practices. To continue to deliver high-value care, hospitalists should review their in-hospital and transitional care practices and start building relationships with high-quality PAC providers in their community.

Disclosures: Dr. Burke was supported by a VA Health Services Research and Development Service career development award and by National Institute on Aging grant R03 AG050885. The funders had no role in the design, conduct, interpretation, or presentation of the data. The other authors have nothing to report. The views represented here are those of the authors and do not necessarily represent the views of the Department of Veterans Affairs.

\section{References}

1. Kosecoff J, Kahn KL, Rogers WH, et al. Prospective payment system and impairment at discharge. The 'quicker-and-sicker' story revisited. JAMA. 1990;264(15):1980-1983

2. Burke RE, Juarez-Colunga E, Levy C, Prochazka AV, Coleman EA, Ginde AA. Patient and hospitalization characteristics associated with increased postacute care facility discharges from US hospitals. Med Care. 2015;53(6):492-500.

3. Jones CD, Ginde AA, Burke RE, Wald HL, Masoudi FA, Boxer RS. Increasing home healthcare referrals upon discharge from U.S. hospitals: 2001-2012. J Am Geriatr Soc. 2015;63(6):1265-1266.

4. Burke RE, Juarez-Colunga E, Levy C, Prochazka AV, Coleman EA, Ginde AA. Rise of post-acute care facilities as a discharge destination of US hospitalizations. JAMA Intern Med. 2015;175(2):295-296.

5. Chandra A, Dalton MA, Holmes J. Large increases in spending on postacute care in Medicare point to the potential for cost savings in these settings. Health Aff (Millwood). 2013;32(5):864-872.

6. Mor V, Intrator O, Feng Z, Grabowski DC. The revolving door of rehospitaliza tion from skilled nursing facilities. Health Aff (Millwood). 2010;29(1):57-64

7. Kramer A, Fish R, Min S. Community Discharge and Rehospitalization Outcome Measures (Fiscal Year 2011): Final Report. Denver, CO: Providigm. http://67.59.137.244/documents/Apr13_CommunityDischarge_CONTRACTOR.pdf. Published April 15, 2013. Accessed March 24, 2016.

8. Burke RE, Whitfield EA, Hittle D, et al. Hospital readmission from post- acute care facilities: risk factors, timing, and outcomes. J Am Med Dir Assoc. 2016;17(3):249-255

9. Levinson DR. Adverse Events in Skilled Nursing Facilities: National Incidence Among Medicare Beneficiaries. Washington, DC: Office of the Inspector General, US Dept of Health and Human Services. Report OEI-06-11-00370. http:// oig.hhs.gov/oei/reports/oei-06-11-00370.pdf. Published February 2014. Accessed March 5, 2014.

10. Ouslander JG, Naharci I, Engstrom G, et al. Lessons learned from root cause analyses of transfers of skilled nursing facility (SNF) patients to acute hospitals: transfers rated as preventable versus nonpreventable by SNF staff. J Am Med Dir Assoc. 2016;17(7):596-601.

11. Kuo YF, Sharma G, Freeman JL, Goodwin JS. Growth in the care of older patients by hospitalists in the United States. N Engl J Med. 2009;360(11):1102-1112.

12. Kane RL. Finding the right level of posthospital care: "We didn't realize there was any other option for him." JAMA. 2011;305(3):284-293.

13. Newhouse JP, Garber AM. Geographic variation in health care spending in the United States: insights from an Institute of Medicine report. JAMA. 2013;310(12):1227-1228.

14. Kane RL, Lin WC, Blewett LA. Geographic variation in the use of post-acute care. Health Serv Res. 2002;37(3):667-682.

15. Kuo YF, Goodwin JS. Association of hospitalist care with medical utilization after discharge: evidence of cost shift from a cohort study. Ann Intern Med. 2011;155(3):152-159.

16. Ward KT, Eslami MS, Garcia MB, McCreath HE. Do internal medicine residents know enough about skilled nursing facilities to orchestrate a good care transition? J Am Med Dir Assoc. 2014;15(11):841-843.

17. Centers for Medicare \& Medicaid Services. CARE Item Set and B-CARE. https://www.cms.gov/Medicare/Quality-Initiatives-Patient-Assessment-Instruments/Post-Acute-Care-Quality-Initiatives/CARE-Item-Set-and-B-CARE. html. Published January 13, 2015. Accessed November 2, 2015.

18. Medicare Payment Advisory Commission. Report to the Congress: Medicare Payment Policy. Washington, DC: Medicare Payment Advisory Commission. http:// medpac.gov/docs/default-source/reports/mar2015_entirereport_revised.pdf. Published March 13, 2015. Accessed December 8, 2015.

19. Block L, Morgan-Gouveia M, Levine RB, Cayea D. We could have done a better job: a qualitative study of medical student reflections on safe hospital discharge. J Am Geriatr Soc. 2014;62(6):1147-1154.

20. Greysen SR, Schiliro D, Horwitz LI, Curry L, Bradley EH. "Out of sight, out of mind": housestaff perceptions of quality-limiting factors in discharge care at teaching hospitals. J Hosp Med. 2012;7(5):376-381.

21. Halasyamani L, Kripalani S, Coleman E, et al. Transition of care for hospitalized elderly patients-development of a discharge checklist for hospitalists. J Hosp Med. 2006;1(6):354-360

22. Hughes SL, Weaver FM, Giobbie-Hurder A, et al.; Department of Veterans Affairs Cooperative Study Group on Home-Based Primary Care. Effectiveness of team-managed home-based primary care: a randomized multicenter trial. JAMA. 2000;284(22):2877-2885.

23. Kinosian B, Taler G, Boling P, Gilden D; Independence at Home Learning Collaborative Writing Group. Projected savings and workforce transformation from converting Independence at Home to a Medicare benefit. J Am Geriatr Soc. 2016;64(8):1531-1536.

24. Segelman M, Szydlowski J, Kinosian B, et al. Hospitalizations in the Program of All-Inclusive Care for the Elderly. J Am Geriatr Soc. 2014;62(2):320-324.

25. Manheim CE, Haverhals LM, Jones J, Levy CR. Allowing family to be family: endof-life care in Veterans Affairs medical foster homes. J Soc Work End Life Palliat Care. 2016;12(1-2):104-125

26. Neuman MD, Wirtalla C, Werner RM. Association between skilled nursing facility quality indicators and hospital readmissions. JAMA. 2014;312(15):1542-1551.

27. Unroe KT, Greiner MA, Colón-Emeric C, Peterson ED, Curtis LH. Associations between published quality ratings of skilled nursing facilities and outcomes of Medicare beneficiaries with heart failure. J Am Med Dir Assoc. 2012;13(2): 188.e1-e6.

28. Schumacher DN, Dobkin ED. Medicare spending per beneficiary. Health Aff (Millwood). 2014;33(10):1878.

29. Das A, Norton EC, Miller DC, Chen LM. Association of postdischarge spending and performance on new episode-based spending measure. JAMA Intern Med. 2016;176(1):117-119.

30. Jubelt LE, Goldfeld KS, Chung WY, Blecker SB, Horwitz LI. Changes in discharge location and readmission rates under Medicare bundled payment. JAMA Intern Med. 2016;176(1):115-117.

31. Federal Register: Medicare Program; Comprehensive Care for Joint Replacement Payment Model for Acute Care Hospitals Furnishing Lower Extremity Joint Replacement Services. https://www.gpo.gov/fdsys/pkg/FR-2015-11-24/pdf/201529438.pdf. Accessed June 20, 2016 
32. Society for Post-Acute and Long-Term Care Medicine. State chapters; AMDA state chapter network. http://www.paltc.org/state-chapters. Accessed June 6, 2016

33. National Association for Home Care $\&$ Hospice. National agency location service. https://agencylocator.nahc.org. Accessed June 6, 2016.

34. Lage DE, Rusinak D, Carr D, Grabowski DC, Ackerly DC. Creating a network of high-quality skilled nursing facilities: preliminary data on the postacute care quality improvement experiences of an accountable care organization. J Am Geriatr Soc. 2015;63(4):804-808.

35. Nyweide DJ, Lee W, Cuerdon TT, et al. Association of Pioneer accountable care organizations vs traditional Medicare fee for service with spending, utilization, and patient experience. JAMA. 2015;313(21):2152-2161.

36. McWilliams JM, Chernew ME, Landon BE, Schwartz AL. Performance differences in year 1 of Pioneer accountable care organizations. $N$ Engl J Med. 2015;372(20):1927-1936

37. Afendulis CC, Kessler DP. Vertical integration and optimal reimbursement policy. Int J Health Care Finance Econ. 2011;11(3):165-179.

38. IPC Healthcare. Post-acute care services. http://www.ipchealthcare.com/advantage/post-acute-care. Accessed January 11, 2016.

39. Society for Post-Acute and Long-Term Care Medicine. Competencies curriculum for post-acute and long-term care medicine. http://www.paltc.org/competenciescurriculum-post-acute-and-long-term-care-medicine. Accessed May 26, 2016.

40. NaviHealth. Leading the way in a rapidly changing PAC marketplace. http:// www.navihealth.us/home/solutions/services. Accessed January 11, 2016.

41. Arbaje AI, Kansagara DL, Salanitro AH, et al. Regardless of age: incorporating principles from geriatric medicine to improve care transitions for patients with complex needs. J Gen Intern Med. 2014;29(6):932-939.

42. Schoenborn NL, Arbaje AI, Eubank KJ, Maynor K, Carrese JA. Clinician roles and responsibilities during care transitions of older adults. J Am Geriatr Soc. 2013;61(2):231-236

43. Burke RE, Kripalani S, Vasilevskis EE, Schnipper JL. Moving beyond readmis sion penalties: creating an ideal process to improve transitional care. J Hosp Med. 2013;8(2):102-109

44. Kripalani S, Jackson AT, Schnipper JL, Coleman EA. Promoting effective transitions of care at hospital discharge: a review of key issues for hospitalists. J Hosp Med. 2007;2(5):314-323.

45. Ouslander JG, Naharci I, Engstrom G, et al. Root cause analyses of transfers of skilled nursing facility patients to acute hospitals: lessons learned for reducing unnecessary hospitalizations. J Am Med Dir Assoc. 2016;17(3):256-262

46. Burke RE, Guo R, Prochazka AV, Misky GJ. Identifying keys to success in reducing readmissions using the ideal transitions in care framework. BMC Health Serv Res. 2014;14:423.

47. Kane RL, Chen Q, Finch M, Blewett L, Burns R, Moskowitz M. Functional outcomes of posthospital care for stroke and hip fracture patients under Medicare. J Am Geriatr Soc. 1998;46(12):1525-1533.

48. Kane RL, Chen Q, Finch M, Blewett L, Burns R, Moskowitz M. The optimal outcomes of post-hospital care under Medicare. Health Serv Res. 2000;35(3):615-661.

49. Greysen SR, Harrison JD, Kripalani S, et al. Understanding patient-centred readmission factors: a multi-site, mixed-methods study [published online January 14, 2016]. BMJ Qual Saf. doi:10.1136/bmjqs-2015-004570.

50. Goodwin JS, Howrey B, Zhang DD, Kuo YF. Risk of continued institutionalization after hospitalization in older adults. J Gerontol A Biol Sci Med Sci. 2011;66(12):1321-1327.

51. Reaves EL, Musumeci M. Medicaid and Long-Term Services and Supports: A Primer. Washington, DC: Kaiser Commission on Medicaid and the Uninsured. Report 8617-02. Henry J. Kaiser Family Foundation website. http://files.kff.org/ attachment/report-medicaid-and-long-term-services-and-supports-a-primer Published December 15, 2015. Accessed May 18, 2016.

52. Bell SP, Vasilevskis EE, Saraf AA, et al. Geriatric syndromes in hospitalized old er adults discharged to skilled nursing facilities. J Am Geriatr Soc. 2016;64(4) 715-722.

53. Cawthon C, Mion LC, Willens DE, Roumie CL, Kripalani S. Implementing routine health literacy assessment in hospital and primary care patients. Jt Comm J Qual Patient Saf. 2014;40(2):68-76.

54. Greysen SR, Stijacic Cenzer I, Auerbach AD, Covinsky KE. Functional im pairment and hospital readmission in Medicare seniors. JAMA Intern Med. 2015;175(4):559-565.

55. Coleman EA, Roman SP. Family caregivers' experiences during transitions out of hospital. J Healthc Qual. 2015;37(1):12-21.

56. Coleman EA, Min SJ. Patients' and family caregivers' goals for care during transitions out of the hospital. Home Health Care Serv Q. 2015;34(3-4):173-184.

57. Coleman EA, Smith JD, Frank JC, Min SJ, Parry C, Kramer AM. Preparing patients and caregivers to participate in care delivered across settings: the Care Transitions Intervention. J Am Geriatr Soc. 2004;52(11):1817-1825.

58. Coleman EA, Ground KL, Maul A. The Family Caregiver Activation in Tran- sitions (FCAT) tool: a new measure of family caregiver self-efficacy. Jt Comm J Qual Patient Saf. 2015;41(11):502-507.

59. Cain CH, Neuwirth E, Bellows J, Zuber C, Green J. Patient experiences of transitioning from hospital to home: an ethnographic quality improvement project. J Hosp Med. 2012;7(5):382-387.

60. Burke RE, Jones J, Ho PM, Bekelman DB. Caregivers' perceived roles in caring for patients with heart failure: what do clinicians need to know? J Card Fail. 2014;20(10):731-738.

61. Coleman EA. Extending simulation learning experiences to patients with chronic health conditions. JAMA. 2014;311(3):243-244

62. Meade LB, Hall SL, Kleppel RW, Hinchey KT. TRACER: an 'eye-opener' to the patient experience across the transition of care in an internal medicine resident program. J Community Hosp Intern Med Perspect. 2015;5(2):26230.

63. American Geriatrics Society. Public policy \& advocacy. http://www.americangeriatrics.org/advocacy_public_policy. Accessed May 26, 2016.

64. Society for Post-Acute and Long-Term Care Medicine. Public policy. http:// www.paltc.org/public-policy. Accessed May 26, 2016.

65. American Academy of Home Care Medicine. Public policy. http://www.aahcm. org/?page=Public_Policy. Accessed May 26, 2016.

66. Hansen LO, Greenwald JL, Budnitz T, et al. Project BOOST: effectiveness of a multihospital effort to reduce rehospitalization. J Hosp Med. 2013;8(8):421-427.

67. Unroe KT, Nazir A, Holtz LR, et al. The Optimizing Patient Transfers, Impacting Medical Quality, and Improving Symptoms: Transforming Institutional Care approach: preliminary data from the implementation of a Centers for Medicare and Medicaid Services nursing facility demonstration project. J Am Geriatr Soc. 2015;63(1):165-169

68. Meehan TP Sr, Qazi DJ, Van Hoof TJ, et al. Process evaluation of a quality im provement project to decrease hospital readmissions from skilled nursing facilities. J Am Med Dir Assoc. 2015;16(8):648-653.

69. Gillespie SM, Olsan T, Liebel D, et al. Pioneering a nursing home quality improvement learning collaborative: a case study of method and lessons learned. J Am Med Dir Assoc. 2016;17(2):136-141

70. Auerbach AD, Kripalani S, Vasilevskis EE, et al. Preventability and causes of readmissions in a national cohort of general medicine patients. JAMA Intern Med. 2016;176(4):484-493.

71. Snow V, Beck D, Budnitz T, et al. Transitions of Care consensus policy statement: American College of Physicians, Society of General Internal Medicine, Society of Hospital Medicine, American Geriatrics Society, American College of Emergency Physicians, and Society for Academic Emergency Medicine. J Hosp Med. 2009;4(6):364-370.

72. Lett JE 2nd. AMDA national engagement in care transitions. J Am Med Dir Assoc. 2011;12(5):387.

73. Haley SM, Coster WJ, Andres PL, et al. Activity outcome measurement for postacute care. Med Care. 2004;42(1 suppl):I49-I61.

74. Jette DU, Stilphen M, Ranganathan VK, Passek SD, Frost FS, Jette AM. AMPAC "6-Clicks" functional assessment scores predict acute care hospital discharge destination. Phys Ther. 2014;94(9):1252-1261.

75. Bowles KH, Ratcliffe SJ, Holmes JH, Liberatore M, Nydick R, Naylor MD. Postacute referral decisions made by multidisciplinary experts compared to hospital clinicians and the patients' 12-week outcomes. Med Care. 2008;46(2):158-166.

76. Kane RL, Bershadsky B, Bershadsky J. Who recommends long-term care matters. Gerontologist. 2006;46(4):474-482.

77. Wald HL, Glasheen JJ, Guerrasio J, Youngwerth JM, Cumbler EU. Evaluation of a hospitalist-run acute care for the elderly service. J Hosp Med. 2011;6(6):313-321.

78. Jones CD, $\mathrm{Vu} \mathrm{MB}$, O'Donnell CM, et al. A failure to communicate: a qualitative exploration of care coordination between hospitalists and primary care providers around patient hospitalizations. J Gen Intern Med. 2015;30(4):417-424.

79. Falvey JR, Burke RE, Malone D, Ridgeway KJ, McManus BM, Stevens-Lapsley JE. Role of physical therapists in reducing hospital readmissions: optimizing outcomes for older adults during care transitions from hospital to community. Phys Ther. 2016;96(8):1125-1134

80. Levy CR, Fish R, Kramer A. Do-not-resuscitate and do-not-hospitalize directives of persons admitted to skilled nursing facilities under the Medicare benefit. J Am Geriatr Soc. 2005;53(12):2060-2068.

81. Boockvar KS, Fridman B, Marturano C. Ineffective communication of mental status information during care transfer of older adults. J Gen Intern Med. 2005;20(12):1146-1150.

82. Kiely DK, Bergmann MA, Murphy KM, Jones RN, Orav EJ, Marcantonio ER. Delirium among newly admitted postacute facility patients: prevalence, symptoms, and severity. J Gerontol A Biol Sci Med Sci. 2003;58(5):M441-M445.

83. Kind AJ, Thorpe CT, Sattin JA, Walz SE, Smith MA. Provider characteristics, clinical-work processes and their relationship to discharge summary quality for sub-acute care patients. J Gen Intern Med. 2012;27(1):78-84.

84. King BJ, Gilmore-Bykovskyi AL, Roiland RA, Polnaszek BE, Bowers BJ, Kind 
AJ. The consequences of poor communication during transitions from hospital to skilled nursing facility: a qualitative study. J Am Geriatr Soc. 2013;61(7):10951102 .

85. Horwitz LI, Jenq GY, Brewster UC, et al. Comprehensive quality of discharge summaries at an academic medical center. J Hosp Med. 2013;8(8):436-443.

86. Tjia J, Bonner A, Briesacher BA, McGee S, Terrill E, Miller K. Medication discrepancies upon hospital to skilled nursing facility transitions. J Gen Intern Med. 2009;24(5):630-635.

87. Vogelsmeier A. Identifying medication order discrepancies during medication reconciliation: perceptions of nursing home leaders and staff. J Nurs Manag. 2014;22(3):362-372

88. Boockvar K, Fishman E, Kyriacou CK, Monias A, Gavi S, Cortes T. Adverse event due to discontinuations in drug use and dose changes in patients transferred between acute and long-term care facilities. Arch Intern Med. 2004;164(5):545-550.

89. Sinvani LD, Beizer J, Akerman M, et al. Medication reconciliation in continuum of care transitions: a moving target. J Am Med Dir Assoc. 2013;14(9):668-672.

90. Scott IA, Hilmer SN, Reeve E, et al. Reducing inappropriate polypharmacy: the process of deprescribing. JAMA Intern Med. 2015;175(5):827-834.

91. Marcantonio ER, Bergmann MA, Kiely DK, Orav EJ, Jones RN. Randomized trial of a delirium abatement program for postacute skilled nursing facilities. J Am Geriatr Soc. 2010;58(6):1019-1026.

92. Callahan CM, Tu W, Unroe KT, LaMantia MA, Stump TE, Clark DO. Transitions in care in a nationally representative sample of older Americans with dementia. J Am Geriatr Soc. 2015;63(8):1495-1502.

93. Givens JL, Mitchell SL, Kuo S, Gozalo P, Mor V, Teno J. Skilled nursing facility admissions of nursing home residents with advanced dementia. J Am Geriatr Soc. 2013;61(10):1645-1650.

94. Gozalo P, Teno JM, Mitchell SL, et al. End-of-life transitions among nursing home residents with cognitive issues. N Engl J Med. 2011;365(13):1212-1221.
95. Ottenbacher KJ, Karmarkar A, Graham JE, et al. Thirty-day hospital readmission following discharge from postacute rehabilitation in fee-for-service Medicare patients. JAMA. 2014;311(6):604-614.

96. Konetzka RT, Grabowski DC, Perraillon MC, Werner RM. Nursing home 5-star rating system exacerbates disparities in quality, by payer source. Health Aff (Millwood). 2015;34(5):819-827.

97. Williams A, Straker JK, Applebaum R. The nursing home five star rating: how does it compare to resident and family views of care? Gerontologist. 2016;56(2):234-242

98. Caplan GA, Meller A, Squires B, Chan S, Willett W. Advance care planning and hospital in the nursing home. Age Ageing. 2006;35(6):581-585.

99. Gade G, Venohr I, Conner D, et al. Impact of an inpatient palliative care team: a randomized control trial. J Palliat Med. 2008;11(2):180-190.

100. Gill TM, Gahbauer EA, Han L, Allore HG. The role of intervening hospital admissions on trajectories of disability in the last year of life: prospective cohort study of older people. BMJ. 2015;350:h2361.

101. Levy C, Morris M, Kramer A. Improving end-of-life outcomes in nursing homes by targeting residents at high-risk of mortality for palliative care: program description and evaluation. J Palliat Med. 2008;11(2):217-225.

102. Miller SC, Lima JC, Looze J, Mitchell SL. Dying in U.S. nursing homes with advanced dementia: how does health care use differ for residents with, versus without, end-of-life Medicare skilled nursing facility care? J Palliat Med. 2012;15(1): 43-50.

103. Halm EA, Magaziner J, Hannan EL, et al. Frequency and impact of active clinical issues and new impairments on hospital discharge in patients with hip fracture. Arch Intern Med. 2003;163(1):108-113.

104. Thomas KS, Mor V, Tyler DA, Hyer K. The relationships among licensed nurse turnover, retention, and rehospitalization of nursing home residents. Gerontologist. 2013;53(2):211-221 